\title{
Nusantara: Delineating Its Authentic Map Based on Indigenous Sources
}

\author{
Anwar OdM ${ }^{1 *}$, Zulayti Zakaria² and Wan Ahmad Fauzi bin Wan Hashim ${ }^{3}$ \\ ${ }^{1}$ Faculty of Applied Social Sciences, Universiti Sultan Zainal Abidin (UniSZA), Gong Badak, 21300 Terengganu, Malaysia \\ ${ }^{2}$ Faculty of Applied Social Sciences, UniSZA, d/a Dean Faculty of Languages and Communication, Universiti Sultan Zainal Abidin (UniSZA), Gong Badak, 21300 \\ Terengganu, Malaysia \\ ${ }^{3}$ Faculty of Law, Nasional University of Malaysia (UKM), 43600 Bangi, Selangor, Malaysia
}

\begin{abstract}
To date, there is yet a map of Nusantara and the understanding of its geographical area is based on logical assumption that it is a combination of 'nusa' (nation) and 'tara' (between) which is not so. This paper is an effort to subdue its absence by delineating its the map in a diagrammatic presentation based on indigenous sources which directly related to it, Nāgara-Kěrtāgama (the $14^{\text {th }}$ century Javanese Majapahit court chronicle) and supported by other indigenous sources, namely, Pararaton (14 century) and the Malay Annals (Sejarah Melayu) (17 Based on these indigenous sources, affirm that Nusantara is an indigenous geopolitical region which covers a vast area of southeastern part of present Asian region with its northern tip starts from the Isthmus of Kra (southern Thailand) and stretches down to its southern tip at Western Papua New Guinea; and its western tip starts from west Sumatera (Barus) and stretches eastward to its eastern tip at Manila (Saludung/Salurong). The objective of this paper is to reify the map of Nusantara so that it could easily visualized by everybody with all level of knowledge.
\end{abstract}

Keywords: Nāgara-Kěrtāgama; Authentic; Langkasuka; Western Papua New Guinea (Waning) ; Manila (Saludung/Salurong)

\section{Introduction}

Nusantara is an ancient indigenous geographical term to refer Southeast Asia [1]. The term 'Nusantara' itself precisely stated in indigenous historical records, namely, the $14^{\text {th }}$ century NāgaraKěrtāgama, Pararaton ( $14^{\text {th }}$ century) and the Malay Annals (Sejarah Melayu) (1 $17^{\text {th }}$ century), denotes a unified territory composing entire indigenous countries in the region currently called Southeast Asian. The term is still in common among the natives of Indonesia, Malaysia, Brunei Darussalam, Singapore and south Thailand. Its importance is beyond academic interests as it plays practical roles in those nations. For instance, it has played an important role in the struggle of Indonesian independence as, since early 1920's, the term 'Nusantara' had been capitalized by Indonesian nationalist circles such as E.F. Douwes Dekker, Ki Hadjar Dewantara and Sukarno (to name some of them) to surrogate the colonial term 'Netherlands Indies' [2-4]. On the other hand, 'Nusantara' is a special kind of 'sacred' word among the indigenous of Southeast Asia as it fertilizes potent feelings of an imagine communities, a form sense of belonging that often pronounced as 'a compatriot kin' (bangsa serumpun) based on their common ancestors and similarities of spoken language, belief, way of lifestyle, skin colours, besides domicile [5].

Notwithstanding its importance, there is yet a map of Nusantara diagrammatically drawn based on authentic sources, and worse still there is yet a direct annotation of what does it really mean. The task of this paper is to unearth the authentic sources that provide evidences, first, to prove Nusantara is not a myth, and secondly, to subdue the absence of Nusantara's map. It is hoped that our efforts could facilitate everybody at all levels of knowledge to easily visualize and understand the Nusantara more objectively, or at least could help the term to be used more intelligently.

This paper will not delve into the issue of ownership of Nusantara. While the choice is always up to the readers, currently, however, Nusantara is not been perceived as the property of Indonesians alone as it been shared by other indigenous peoples in this region as well, including Malaysia, Brunei, south Thailand, the Philippines and Singapore. The ultimate intention of this paper is to enhance the sharing potent feelings of imagine communities among the communities that will conserve the everlasting peaceful, prosperous and tranquility lives of the region.

\section{The Authentic Map of Nusantara}

There is no authentic map of Nusantara other than the one been constituted from authentic sources. As above mentioned, the most important and authentic source about Nusantara is Nāgara-Kěrtāgama [6]. It is from this source that we could delineate the map Nusantara diagrammatically. This is stated in its $13^{\text {th }}$ and $14^{\text {th }}$ Pupuhs (passages):

All houses shining glittering colors, matching the moon and the sun, incomparable beautiful, countries (nagaras) under Nusantara with Daha as the leader, solemnly bowed and sheltering under Wilwatikta (the King of Majapahit) (Figure 1).

\section{The detail of each of the countries subordinated under} Nusantara (Majapahit) is as follow

The foremost is the kingdom of Melayu which included: Jambi, Palembang, Toba and Darmasraya, and should also be mentioned the districts of Kandis, Kahwas, Minangkabau, Siak, Rokan, Kampar and Pane Kampe, Haru as well Mandailing, Tamihang, the kingdoms Perlak and Padang Lwas with Samudra as well Lamuri, Batan, Lampung and also Barus.

Those are the most important Melayu kingdoms which bow to Majapahit

*Corresponding author: Anwar OdM, Faculty of Applied Social Sciences, Universiti Sultan Zainal Abidin (UniSZA), Gong Badak, 21300 Terengganu, Malaysia, Tel: 60 129342568; E-mail: odmanwar@unisza.edu.my

Received August 10, 2016; Accepted September 05, 2016; Published September 13, 2016

Citation: Anwar OdM, Zakaria Z, Hashim WAFW (2016) Nusantara: Delineating Its Authentic Map Based on Indigenous Sources. Intel Prop Rights. 4: 163. doi: 10.4172/2375-4516.1000163

Copyright: ( 2016 Anwar OdM, et al. This is an open-access article distributed under the terms of the Creative Commons Attribution License, which permits unrestricted use, distribution, and reproduction in any medium, provided the original author and source are credited. 


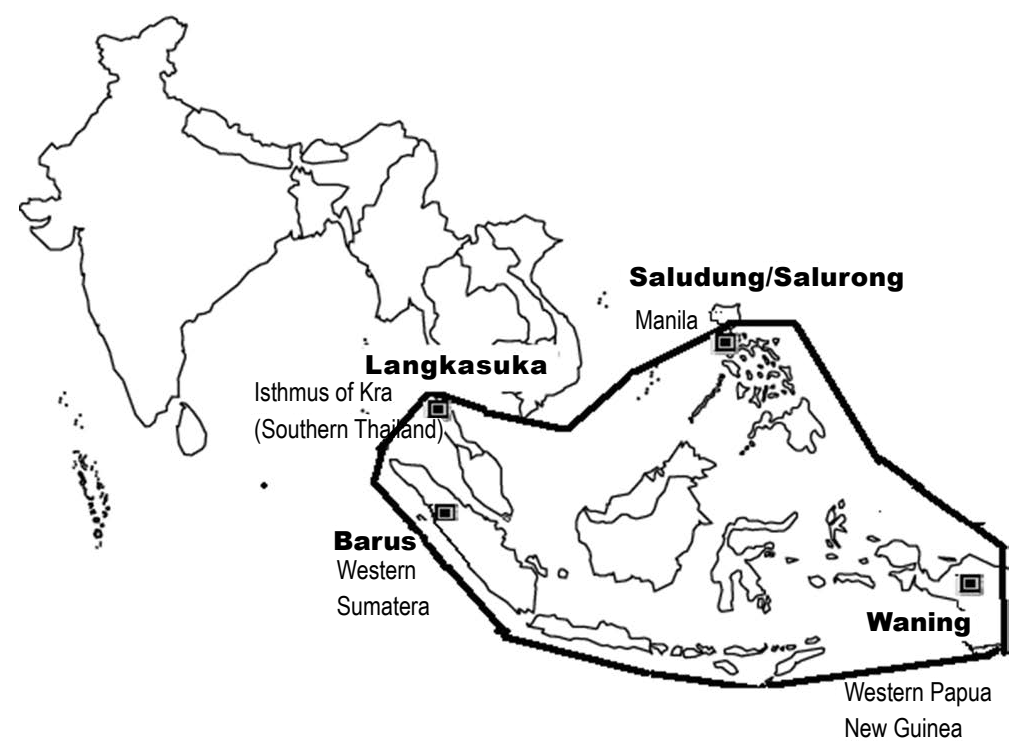

Source: Nāgara-Kĕrtāgama (1365) edited by Slamet Mulyana (1979: 279-281)

Figure 1: Map: The Map of Nusantara.

The kingdoms under Tanjungnegara Island included: KapuasKatingan, Sampit, Kota Lingga, Kota Waringin, Sambas, Lawal, and should also be mentioned Kadandangan, Landa Samandang and Tirem, and not to forget Sedu, Barune, Kalka, Saludung/Salurong (Manila), Solot (Sulu) and also Pasir Barito, Sawaku, Tabalung, and also Tanjung Kutei.

Malano is still the most important in Tangjungpura Island

In Hujung Medini: Pahang has to be mentioned first, follows by Langkasuka, Saimwang, Kelantan as well as Trengganu, Johor, Paka, Muar, Dungun, Tumasik, Kelang and Kedah, Jelai, Kanjapiniran, all are long assembled under Majapahit

In east of Java: Bali is the most important kingdom, Badan and Lo Gajah Gurun as well as Sukun, Taliwang, Pulau Sapi and Dompo Sang Hyang Api, Bima, Serantau, Hutan Kendali are at once. Pulau Gurun which commonly called as Lombok Merah with posporous Sasak has been entirely under its control, Bantayan in the province of Bantayan as well as Lombol Merah up to Udamakatraya and other islands.

\section{Of kingdoms under Makassar}

There are Makasar Islands, Buton, Banggawi Kunir, Galian Salayar, Sumba, Solot, Muar, Wanda (n), Ambon or Maluku Islands, Waning, Serantau, Timor, and a number of other islands.

Dwipantara (archipelago partners): These are the name of foreign nations which have relationships with Majapahit and have good relationship with Siam and Ayudyapura, as well as Darmanagari, Marutma, Rajapura, as well as well as Singanagari Campa, Kemboja and Yawana (Nāgara-Kěrtāgama, Pupuh XII-XIII. Transliterated into bahasa Indonesia by Slametmulyana [7].

We could now draw the map of Nusantara the way a standard procedure undertaken by cartographer: Firstly, we need to gather the details of projected map. Secondly, we need to identify the edges of the projected map. Thirdly, we need to joint those edges into a complete circle.
All the details to constitute the map of Nusantara have been given in the above passages (pupuh) of Nāgara-Kerrtāgama. During the $14^{\text {th }}$ century, it was the combination of those countries under a single Javanese Majapahit empire that constituted the map of Nusantara. As universally known fact, the edges of any map are defined by farthest places of its boundaries in all it directions - north, south, east and west. As underlined in, it is obvious that the edge of Nusantara in its north direction is Langkasuka, and in its south is Waning, in its east is Saludung/Salurong, and in its west is Barus. It is being stressed that these edges are defined by the virtue of their locations at the farthest reach in their respective directions (Table 1).

Nusantara map will be established when the four points of those edges are jointed together. To serve our purpose in this limited space of paper, it is suffice to joint those edges in straight lines. The joining all these edges will constitute the outline the map of Nusantara. Hence, as could be substantiated by the information listed in the $13^{\text {th }}$ and $14^{\text {th }}$ pupuh (passages) of Nāgara-Kěrtāgama as shown in Table 1, Nusantara could be defined is a unified geopolitical territory enclosure with its northern tip boundaries start at the Isthmus of Kra (southern Thailand), formerly known as Langkasuka; and it stretches southward to Western Papua New Guinea (Waning); and its western tip boundaries start at west Sumatera (Barus) and stretched eastward to Manila (Saludung/ Salurong).

Nusantara's area coverage could also be conceptualized from two dimensions: horizontally and vertically. Horizontally, it spread from southern Thailand to Western Papua New Guinea; and vertically, from western Sumatera (Barus) to the Philippines (Saludung/Salurong, or currently Manila).

As noted in Nāgara-Kěrtāgama, there was another entity related to Nusantara that consisted of Thailand, Sri Lanka, Myanmar, Cambodia, Vietnam, Laos and China (or Sin). They were grouped as Dwipantara. These countries had a very long standing historical relationship with the countries in Nusantara. They worked as partners or as acquainting friends with Nusantara [5]. The relationships still exist till today. It operates on the same basis of present ASEAN relationships and 


\begin{tabular}{|l|l|}
\hline \multicolumn{1}{|c|}{ Core Nations } & \multicolumn{1}{c|}{ Subdivisions } \\
\hline Melayu & $\begin{array}{l}\text { Jambi, Palembang, Toba, Darmasraya, Daerah Kandis, Kahwas, Minangkabau, Siak, Rokan, Kampar, Pane Kampe, Haru, } \\
\text { Mandailing, Tamihang, Perlak Padang Lwas, Samudra, Lamuri, Batan, Lampung and Barus }\end{array}$ \\
\hline Tanjungnegara & $\begin{array}{l}\text { Kapuas-Katingan, Sampit, Kota Lingga, Kota Waringin, Sambas, Lawal, Kadandangan, Landa Samandang, Tirem, Sedu, Barune } \\
\text { (Brunei), Kalka, Saludung, Solot, Pasir Barito, Sawaku, Tabalung, Tanjung Kutei, Malano }\end{array}$ \\
\hline Hujung Medini & Pahang,Langkasuka,Saimwang,Kelantan, Trengganu, Johor, Paka, Muar, Dungun, Tumasik, Kelang, Kedah Jelai, Kanjapiniran \\
\hline Jawa & $\begin{array}{l}\text { Bali, Badahulu, Lo Gajah, Gurun, Sukun, Taliwang, pulau Sapi, Dompo, Sang Hyang Api, Bima, Serantau, Hutan Kendali, Pulau } \\
\text { Gurun, Lombok Merah, Sasak, Bantayan Bantayan, kota Luwuk, Udamakatraya and the other islands in its surrounding }\end{array}$ \\
\hline Makkasar & $\begin{array}{l}\text { Buton, Banggawi, Kunir, Galian, Salayar, Sumba, Solot, Muar, Wanda (n), Ambon, Maluku, Waning, Serantau, Timor and some other } \\
\text { islands in its surrounding }\end{array}$ \\
\hline Adjacent Nations & $\begin{array}{l}\text { Syangka together with Ayudyapura, as well as Darmanagari, Marutma, Rajapura, as well as Singanagari, Campa, Kemboja and } \\
\text { Yawana as acquainting friends }\end{array}$ \\
\hline Dwipantara (archipelago partners)
\end{tabular}

Source: Nāgara-Kěrtāgama (1365) edited by Slamet Mulyana (1979: 279-281).

Table 1: Nations that constituted Nusantara in $13^{\text {th }}-14^{\text {th }}$ centuries.

partnership with other nations such as with Japan, China, India, USA, $\mathrm{EU}$ and so forth.

\section{Some notes on Langkasuka, Manila and Western Papua New Guinea}

Some observers, such as Wolters [8], Slamet Muljana [7], Rustam A. Sani [9] raised doubt about the significance of Nāgara-Kěrtāgama as the source of Nusantara. They opine that the information in Nāgara-Kěrtāgama should not be accepted as something true because they are just the imaginations of its author (Prapancar) to glorify his kingdom during its declination. Wolters [8] says the countries listed under Javanese Majapahit are not genuine, instead "The centers he (Prapancar) lists as 'tributaries' or as being 'protected' are probably compiled from commercial intelligence circulating in Majapahit's ports" However, Wolters' statements, as well as the others observers, need to be reexamined because there are ample evidences to support the notions given in Nāgara-Kěrtāgama on the Javanese Majapahit are not far away from the truth. First: The notion that Majapahit had subjugated its neighbors to the east as far as Manila, to north as far as south Siam (Langkasuka), to the west as far as Barus, and to the south as far as western Papua New Guinea is not just mentioned in a single source of Nāgara-Kěrtāgama. There are other sources that give similar facts such as Pararaton, the Malay Annals (Sejarah Melayu) and Hikayat Raja-Raja Pasai. Information furnish by Pararaton are as follow:

Sira Gajah Madapatih Amangkubhumi, the Prime Minister (of Javanese Majapahit), said he will not taste any spice, said Gajah Mada, "as long as I do not unify Nusantara, I will not taste any spice. Before I conquer the country of Gurun, country of Seram, Tanjungpura, country of Haru, country of Pahang, Dompo, country of Bali, Sunda, Palembang, Tumasik, I will never taste any spice.” From Raden Mas Mangkudimedja \& Harjana Hadipranata [7].

Those countries mentioned in Pararaton spread in a vast area including the Malay Peninsula (inherently include the Isthmus of Kra), Sumatera, Kalimantan, Bali, and the countries toward Papua New Guinea.

And the Malay Annals (Sejarah Melayu), a Malay text of the 15th and 16th centuries of Melaka Sultanate, says:

As relates by traditions, there is Betara Majapahit. His Highness got two sons from his marriage with the daughter of the king of Bukit Seguntang (Mount of Seguntang). The elder, named Raden Inu Merta Wangsa. He is appointed as the king of Majapahit. The younger, named Raden Mas Pamari, is also appointed as the king of Majapahit because this kingdom is very large. As the times passed, Betara Majapahit vanished (died). His elder son was appointed to His Highness position (as the Betara Majapahit). His kingdom is extremely large. During that time, the whole of Javanese island is under His Highness jurisdiction (hukum). Some of the kings in Nusantara have already been colonized by His Highness. As Betara Majapahit heard that Singapura was a big kingdom, and its kingdom did not bow to His Highness, and the Singapura's king was his cousin [10].

The phrase that says "the whole of Javanese island is under His Highness (Majapahit Kingdom) jurisdiction (hukum) and some of the kings in Nusantara have already been colonized by His Highness" is about the vast area under Javanese Majapahit.

Second: Information furnishes by the $14^{\text {th }}$ century Hikayat RajaRaja Pasai are almost the as the other indigenous sources. This Hikayat (passim) has listed the political establishments under the Javanese Majapahit empire as follow: Balambangan, Bandan, Bandjar Masin, Bangoran, Beroumak, Bilitong, Bima, Bintan, Bulang, Djamadja, Karantouk, Karimata, Kontei, Lingga, Mampawa, Pemanggilan, Poulo Laut, Poulo Ringgi, Riau, Sardsar, Siantan, Soukadana, Souwabi, and Tambalan. This means, according to this $14^{\text {th }}$ century indigenous source, Majapahit empire covered almost the whole of present Southeast Asian region.

Third: The rise of Javanese Majapahit power during that period $13^{\text {th }}$ and $14^{\text {th }}$ centuries century was still remembered by the people who were living in the 16th century Melaka. It was recorded by Tome Pires in his Suma Oriental when he was in Melaka from 1512 to 1515: They say that the island of Java used to rule as far as the Moluccas (Maluco) on the eastern side and (over) a great part of the west; and that it had almost all the islands of Sumatra under its dominion and all the islands known to the Javanese, and that it had all this for a long time until about a hundred years ago, when its power began to diminish [11].

Fourth: The ancient Nusantara geopolitical boundaries were still traceable during the period of early modern European explorers came to this region. For instance, Crawfurd [12], who was living in Sumatera and collecting huge cultural and historical material in the vast area of Nusantara since the second part of 18th century left these notes: The Archipelago contains three islands of the first rank in size, namely, Borneo, New Guinea, and Sumatra. Of the second rank, it contains a peninsula and an island, viz. Java and the Malayan peninsula. Of the third rank, it contains three islands, viz. Celebes, Luzon or Luconia, and Mindanao, each of them equal in size to the greatest island of America. Of the fourth rank, it contains at least sixteen, which are as follow, beginning from the westward, viz. Bali, Lambok, Sambawa, Chandana, Mores or Mangarai, Timar, Ceram, Buroe, Gilolo, Palawan, Negros, Samar, Mindoro, Panay, Leytey and Zebu. 
All these sources convey evidence that there was a time in the past that all the countries in this region once under a single unified empire. They testified the extension of Javanese Majapahit which covered the southern Thailand, the Philippines and other as mentioned above.

There has been a consensus in all historical sources that Langkasuka was a native kingdom located in southern part of present-day Thailand, especially around present Patani and Nakhon Si Thammarat [13]. It flourished back to around the first century $\mathrm{AD}$, but declined since early $14^{\text {th }}$ century $[14,15]$. As illustrated in Table 1 , during the $13^{\text {th }}$ and $14^{\text {th }}$ centuries Langkasuka was one of the political establishments under the kingdom of Hujung Medini. And, as stated in Nāgara-Kěrtāgama, the kingdom of Hujung Medini was an indigenous empire located in present Pahang. During that period (in $14^{\text {th }}$ century), it was under the Javanese Majapahit empire. In Nāgara-Kěrtāgama, as it was located at the farthest reach of Majapahit empire in the north, Langkasuka was the edge of Nusantara in its northern region.

Perhaps, some readers may wonder about the position of Manila as one of the establishment under Nusantara. It should be observed that it is not Nāgara-Kěrtāgama alone that supplies the facts that the Philippines was once under the sway of Javanese Majapahit empire but other evidences such as cultural and historical materials, language and the people. For instance, the present of Visaya and Bisaya in the Philippines. Visaya is a geographical term that covers islands between Luzon and Mindanao, and Bisaya are the people living in Visayan Islands [16,17]. It had been an established fact, especially among the local of Manila, that the old name of Manila was 'Saludung' or 'Salurong' [18,19]. As profoundly illustrated in Table 1, NāgaraKěrtāgama mentioned that in $14^{\text {th }}$ century 'Saludung' or 'Salurong' was one of the establishment under the empire of Javanese Majapahit

Another important facts related to Nusantara is its relations to western Papua New Guinea. Its old name was Waning. According to Nāgara-Kěrtāgama, in the historical period, it was under the empire of Javanese Majapahit. As it is located at the farthest reach of Majapahit empire in the south, western Papua New Guinea is the edge of Nusantara in its southern region. As stated in the $13^{\text {th }}$ and $14^{\text {th }}$ passages of Nāgara-Kěrtāgama, Waning is one of the native establishment under Makassar kingdom.

It would not an exaggeration to allude that the extension of Nusantara's boundaries are as identical to the spread of Javanese Majapahit's kingdom. However, this is true only during the $14^{\text {th }}$ century. The way how Nāgara-Kerrtāgama, Pararaton and the Malay Annals presented the information are soundly enough that Nusantara was already there during the time before the Javanese Majapahit extending its empire. Pararaton gives quite clear notion on this: "as long as I do not unify Nusantara ...” By this phrase it means Nusantara had already existed but was devasted by other forces, and the Javanese Majapahit Kingdom wished to reunite it back.

The ealier existence of Nusantara is profoundly clear stated in Sejarah Melayu [10,18-21] that says: "During that time, the whole of Javanese island is under His Highness jurisdiction (hukum). Some of the kings in Nusantara have already been colonized by His Highness." The phrase "some of the kings in Nusantara" by itself means Nusantara had already existed before Javanese Majapahit kingdom.

\section{Conclusion}

We hope we have furnished fairly clear and concrete as well as authentic evidences that Nusantara is not a myth, but a real and concrete existence. Based on available sources in our time, namely, Nāgara-
Kèrtāgama, Pararaton and the Malay Annals (Sejarah Melayu), we conclude that Nusantara had already existed long before the Javanese Majapahit but during the $14^{\text {th }}$ century its coverage was the extension of the this empire. To sum up, Nusantara is a geopolitical enclosure or circle of various local political units which spread in the vast area of present Southeast Asia with its northern tip boundary starting from Isthmus of Kra (Langkasuka), its eastern tip at Manila (in the Philippines), its southern tip at Western Papua New Guinea (Waning), and its western tip at north-west Sumatera (Barus). Comparatively, Nāgara-Kerrtāgama gives the most complete toponyms of Nusantara. However, all those sources (including Pararaton and the Malay Annals) had recorded that Nusantara was constituted by the convergence of the countries in present Southeast Asia. And by not putting more words, the map of Nusantara is as illustrated as Map 1 in Figure 1.

\section{References}

1. Gonda J (1973) Sanskrit in Indonesia. International Academy of Indian Culture, New Delhi, India.

2. Vlekke, Bernard HM (1959) Nusantara; A History of the East Indian Archipelago Cambridge, Mass.: Harvard University Press, USA

3. Resink GJ (1960) Indonesia's History between the Myths. The Hague.

4. Russell J (1973) Earl, Logan and 'Indonesia.' In Archipel 6: 93-118.

5. Anwar OM (2016) Contextualizing Nusantara Studies. In Journal of Nusantara Studies 2016, Vol 1(1) Terengganu: Universiti Sultan Zainal Abidin. Journal of Nusantara Studies 1: 1-6.

6. Mei DVD (2011) Kakawin Sutasoma and Kakawin Nāgara Krtāgama BijdragentotdeTaal-Land-enVolkenkunde 167: 322-332.

7. Pararaton S, Mangkudimedja RM, Hadipranata H (1979) Serat Pararaton (Ken Arok), (Vol1)Proyek Penerbitan Buku Bacaan dan Sastra Indonesia dan Daerah.

8. Wolters OW (1982) History, Culture, and Region in Southeast Asian Perspectives. Singapore: Institute of Southeast Asian Studies, USA.

9. Sani AR (1976) Melayu Raya as a Malay 'Nation of intents.' Dalam H.M. Dahlan (ed.) The nascent Malaysia society. Bangi: Universiti Kebangsaan Malaysia.

10. Annals M (1977) Museums, History and Culture in Malaysia, the. ed. Shellabear Kuala Lumpur: Fajar Bakti.

11. Tomeji P (1944) The Suma Oriental, and The Book of Francisco Rodrigue. Ed and transl. A. Cortesao. Vol. II Hakluyt Society, London.

12. Crawfurd JA (1819) History of The Indian Archipelago: Containing an Account of the Manners, Arts, Languages, Religions, Institutions, and Commerce of its Inhabitants. Vol. II. Edinburgh: Printed for Archibald Constable and Co. Edinburgh; and Hurst, Robinson, and Co. Cheapside, London.

13. Wales HGQ (1976) The Malay peninsula in Hindu times. Journal of the Malaysian Branch of the Royal Asiatic Society 51: 149-152.

14. Cribb R (2013) Historical Atlas of Indonesia. London: Routledge.Nia press, Denmark.

15. Funston, N 2008, Southern Thailand: The Dynamics of Conflict, Institute of Southeast Asian Studies (ISEAS), Singapore.

16. Hsiu-chuan L, Rubino CRL (2005) Current Issues in Philippine Linguistics and Anthropology. Linguistic Society of the Philippines and SIL Phillipines.

17. Artemio RG (2012) Historical Dictionary of the Philippines. Scarecrow Press, London.

18. Nakpil CG (2003) Carmen Nakpil: Manila Under The Muslims.

19. Hose C, William Mac- D, Haddon CA (1966) The Pagan Tribes of Borneo (Vol. 1) Frank Cass, London.

20. Hogle JE (2014) The Cambridge Companion to the Modern Gothic. Cambridge: Cambridge University Press, London.

21. Nick J (1990) Manila, My Manila: A History for the Young. City of Manila: Anvil Publishing, Union Streets Mandaluyong City. 